\title{
A READING FROM THE BOOK OF BEGINNINGS \\ or \\ THE END OF THE LINE
}

\author{
By Ailbhe Smyth \\ WERRC, University College Dublin
}

Copyright (c) 2005 by Ailbhe Smyth. This text may be archived and redistributed in electronic form, provided that the author and journal are properly cited and no fee is charged for access. Archiving, redistribution, or republication of this text on other terms, in any medium, requires the notification of the journal and consent of the author.

\section{FIRST BEGINNING}

Does the postmodern age signal the end of the 'grand narratives'?

(So they ask me, and others like and unlike me.)

\section{Riddle}

How to answer a statement masquerading as a question?

Question the statement

What comes after the question?

This is what I wrote afterwards:

They must think I know something about endings or narratives or both.

Otherwise why ask me?

Don't they know I am a construction not at all original and quite unauthorised.

That my solidity lies on foundations I have not put down?

It lies, my solidity.

Fraudulent fiction.

Can I have misled?

No lack of example

plenty of models lying around the place all deriving from the one anyway. 
Given the wrong impression?

Impressed

printed

the self is not the same.

The words lie coolly on the page

removed from fleshy interference

collected collaged

into an appearance of coherence

(in heat and difficulty)

from here and there

un peu partout

(with and without pretension)

Always speaking in tongues

other than my own.

Does this mean lies?

\section{2}

Many have the gift of the tongue but nothing to say. Do not listen to them. Many who have words and tongue have no ear, they cannot listen and they will not hear!

\section{(Gloria Anzaldua)}

I listen to her warning

Take it to heart

Although it is, may be,

about me

not for me.

Warning from 'a poor chicanita from the sticks'.

I hear your words

Chicanita Gloria

And will take care

To say less.

But what of the listeners?

\section{3}

Of course, I have credentials

And protections

Currently negotiable

Of skin of class of education

(for what it's worth).

Connections not at all coincidental to anything.

But what price my sex and nationality?

And all the rest

I cannot say in any tongue?

Mere markers of permitted ex-centricity?

The acceptable face of subversion?

Marketable revolution par personne interposee? 
What price my education?

There is so much

I just can't make

head or tail of.

Can't get my tongue around

dense sense abstractions

latinate hyphenates

syntactical circulations.

I am not naive

far less innocent.

I know the 'old simplicities'

no longer function.

But who - which 'we' — can speak

The new complexities?

'Old gardens are not relevant'

\section{(Mary O'Donnell)}

she said severely 'reading sunflowers in September'

(And a propos of something rather different

A woman's life, I think it was)

And she was quite right, of course.

New gardens are not necessarily

fabrications.

But they frighten me to silence

Almost.

There is not one truth,

I know.

Reason, Science, Progress

and all the rest

have gone the way of all

flowers

And I celebrate.

But I don't always understand

quite simply

the words that killed them.

I notice that it is only when my mother is working in her flowers that she is radiant almost to the point of being invisible - except as Creator: hand and eye. She is involved in work her soul must have. Ordering the Universe in the image of her personal conception of Beauty.

\section{(Alice Walker)}

And the Universe begat a multiverse

(Who knows this

in the age of communication par excellence?)

It may be more truthful

But what price brilliance and sophistication

If it leaves the old plots 
largely undisturbed

for most?

Of course, when more abstract writing is seen as more important, the language of underclass women is a speech then that has no relevance. When black women confronted feminist movement, urging inclusion of race and racism, this was revolutionary, Yet now the new terms of this discussion suggest that words like race and racism are inappropriate, not sophisticated, too simplistic. Currently, the discussion of race takes place within the framework of 'colonial discourse'. How many women and men know what that means?

(Bell Hooks)

New gardens are not everywhere appropriate.

\section{PLOT (OED)}

Relevant definitions:

1. The outline, plan or scheme of a play, poem, work of fiction etc

2. A piece (of small or moderate size) of ground, or what grows or lies upon it.

Appropriate meanings:

1. Heroic exploits grand adventures linear progress

2. Our own place — naming the ground we're coming from (Adrienne Rich)

\section{6}

Last week, it's a verifiable fact, I was planting polyanthus

A little late in the season

As ever

(Never quite making it into the first bunch of front runners)

Though they'll grow much the same, in my experience,

And thinking - just associatively of course-

That of all the words with poly- at their root

Only one is for a flower

(Though my knowledge is strictly controlled

by contingencies beyond my limits

and univice versa)

Polymeric polynomial polyverse

of polymorphous polytheist polyglots

('There's nowhere you can go and only be with people who are like you. It's

over. Give it up'. Bernice Johnson Reagon)

Requiring polymathic polygraphs

for its elucidation

(Which is the danger and the trap

whether known or not)

('Only the blandest generalities are true in any universal sense'. Michelle

Stanworth) 
POLYGRAPHY has (at least) three meanings (OED), relevant and appropriate:

1. Writing much, treating of many subjects

2. A kind of cipher or secret writing

3. A method of mechanically producing copies of pictures

The tallest flowers hide the strongest nettles (Irish Proverb)

So what I want to know

Is who is leading who up the garden path?

Participating in theoretical language is one thing; feeling as though you have to imitate it even at the cost of feeling committted to what you are saying another.

(Mary Childers)

\section{7}

Seventh part, as in Revelation

Although revealing nothing

The Book of Revelation, properly Re-veilings

(Elizabeth Cady Stanton)

But irony is the thing

even if it stymies you.

Irony is about contradictions that do not resolve into larger wholes, even dialectically, about the tension of holding incompatible things together because both or all are necessary and true. Irony is about humour and serious play. It is also a rhetorical strategy and a political method ....

(Donna Haraway)

Flowering nettles coherent fragments

Safe sex deadly games

and serious play

Controlling freedoms planned obsolescence

bio-technologies genetic engineering

permeable boundaries active discourses

rhetorical action theoretical politics

grand narratives?

Round and round the garden

Infinite loop

And there appeared a great wonder in heaven; a woman clothed with the sun, and the moon under her feet, and upon her head a crown of twelve stars;

And she being with child travailed in birth.

And there appeared another wonder in heaven; and behold a great red dragon, having seven heads and ten horns, and seven crowns upon his heads. 
And his tail drew the third part of the stars of heaven, and the dragon stood before the woman to devour her child as soon as it was born.

Revelation: 12

I half-remember half-forget

when she told me the giant story

And how afraid I was

Because I knew his power

And how he could shatter me to pieces

Like the little girl

Or did he swallow her whole

And entire complete?

The fear is there still

And I told my daughter

A different version

which is not the same story at all.

\section{SECOND BEGINNING}

Which is where I was supposed to begin. And which may or may not be true.

An bfhuil aon sceal agat? they ask in my mother's tongue, I mean the language of her childhood, not mine. Have you a story, have you news?

What have I?

Long piece of pieces.

Poem?

No, not original

although about origins.

Voices in and out

half-caught

catching

playing with saying

bringing others to my surface

where they move about

clumsily

in slow slow motion

not like eely theorists.

I will tell a story I heard recently about a white woman theorist who teaches in an ivy league institution. I overheard a group of white women putting her down for singing a song in class. Singing was a sign that she was less theoretical or was a spectacle. I felt as though I was listening in on a conversation that was also downgrading me, because I have often sung spirituals in class.

(Bell Hooks) 


\section{Riddle}

What is more useful than a reading?

In my end is my beginning and if there is no end nor is there a beginning and vice versa and other such riddles and enigmas.

And world without end and beginning and ends and means endings and meanings.

Which may well not be true.

Puns proliferate but riddles have been relegated. Only my daughter asked me riddles.

Everything is infinite and foolery as well.

\section{(Isak Dinesen)}

Riddles bring opposites together while holding them distinct, transforming through correlation not union. What else is irony?

Through the play of riddles, the great connections and the major equivalences are discovered; it is a subterfuge designed to admit the ineffable into human

discourse.

\section{(Roger Caillois)}

The simultaneity of many worlds, denial of degree.

\section{Riddles}

What is sweeter than mead? -Intimate conversation.

What is blacker than the raven? -Death.

What is whiter than snow? - Truth.

What is swifter than the wind? -Thought.

What is sharper than the sword? -Understanding.

What is lighter than a spark? -The mind of a woman between two men.

(From The Wooing of Ailbe)

Ailbe was the daughter of Cormac who was the son of Etain and of Art who had been raised by a she-wolf. Wooed by Finn mac Cool, Ailbe gave answers to the riddles Finn set her. And then we know no more. The story belongs to Finn, the hero. It is not told if Finn knew the answers to the riddles he set.

The problem, practically, is where to be beginning. Locating the telling. From where can silence speak?

Can stories tell a world without beginning, without ending, without meaning? They say the story's over while for many many many it's only beginning and beginning.

Are we back in mythic time?

'But since we're talking story, perhaps we should, at least, define the parameters of discussion', she said sternly.

\section{(Gail Scott)}

(Para-what? she asked, exasperated) 
How does a woman choose a form to write in? Is there a connection between the form she chooses and the circumstances of her life? Gail Scott.

If there is not, she answered smartly (don't you back-answer me, girl!), why tell a story? No, how tell a story if there are no roots? Where start the story?

Lonely lonely lonely lonely;

A story with a middle only

Paul Durcan

Whose beginning?

Nothing in Genesis. No good for beginning. Suppressed matrix. It is not told how Ailbe was born. Nor Eve. Nor Athene. Absent from birth

Which is not, actually, quite true.

The lie is that Eve was born of rib and Athene of head. Which is a bit peculiar, to put it mildly. Unnatural obstetrics. (Kenneth Burke)

And the rib which the Lord God had taken from man, made he a woman, and brought her unto the man.

Genesis: 2

When Metis, goddess of wisdom who presided over all knowledge was pregnant with Athene, she was swallowed up by Zeus who then gave birth to Athene from his head.

Phallogocentric parthenogenetic births, of one kind and another, all the same. A lot of sliding over facts, myth-making and fooling around.

The basic problem that we have had was believing somebody else's story about us - what we can and cannot do, who we can and cannot be.

\section{(Luisah Teish)}

Playing fast and loose with fact.

Because the practical fact is, or at least it used to be, that mothers you know, fathers you don't.

My mother says Indeed, I am his. I for my part do not know. Nobody knows his own father.

(Telemachus, Odyssey)

Hence high-tech recreations.

Whether or not women are reduced by this process to the level of 'reproductive prostitutes' the object and the effect of the emergent technologies is to deconstruct motherhood and to destroy the claim to reproduction that is the foundation of women's identity.

(Michelle Stanworth) 
The page is never truly blank. Always occupied, colonised. How to blank it out? With origins, way way way before and after and beyond their stories and discoveries and inventions, manipulating eggs and embryos.

Beginnings invented, fantasised, at best skated over. Tricks of birth. Denial of agency and voice and pleasure and laughter.

\section{Sarah's Story}

Now Sarah was listening in at the tent door behind Him and since Abraham and Sarah were aged, well advanced in years, and since the custom of women had ceased with Sarah, she laughed to herself, saying, "Connubial enjoyment for me, worn out as I am, and my master aged too" The Lord asked Abraham, "Why did Sarah laugh just then, saying, 'How could I possibly bear a child, aged as I am?' Is anything beyond the Lord's reach? At the appointed time I will return to you, at the reviving season and Sarah will have a son." Feeling afraid, Sarah made denial, "I did not laugh." He said, "No, but you did laugh."

Genesis: 18

My place of origin is not indifferent if different.

We are obsessed with origins, though we deny it of course. Origins are definitively passe. The Origins and Causes of Oppression. Deleted from the agenda. Cancelled. Abort, fail, the machine says.

We? We are the ones (the few) exempt from ordinary curiosity, smooth rootless sophisticates, contemptuous of commonplace. We are the strippers of myth, exposers of the phallacy of The Truth, The Self, The Progress, The Reason, The Knowledge, The Universe. Zealously ruthless in our mission. We are the flashers of The Word.

A Cyborg is a cybernetic organism, a hybrid of machine and organism, a creature of social reality as well as a creature of fiction ... Cyborg replication is uncoupled from organic reproduction.

\section{(Donna Haraway)}

\section{Riddle:}

Which is closest to the origin - a replica or a duplicate?

Androgynous or androcentric copies? Barely a whisper of a difference. Emulation mode.

Begin at the end of the Great Book of the Father and the Son. In Revelation. 'Ah, but God may like a world turned upside down!'

\section{(Isak Dinesen)}

(Mind you, I'm not the only one. Great minds think alike, fools seldom differ and better late than never, tra la la.) 
Curiously, 'Celtic tradition has preserved no native story of the creation of the world and of man.'

(Rees and Rees)

But now they have made the Great Book of Ireland. Made of vellum by poets and artists, skin to skin. The skins of calves, still-born or aborted, called slicks. How slick? No-tech becomes high-cool. Recto and verso. Chapter and verse, the Great Book is much the same. Certainly, it is not the book of the Mother and the Daughter. Inscribed in gold, embellished, excessively signed, authorised, sponsored. Culture in the bank, guaranteed repository, the world undisturbed. How very disturbing.

The father-son, cause-effect, author-text, genealogy of all genealogies is in the book of Numbers. Patrilinear paradigm.

Para-what? she asked again. Talk to me straight. Tell me what you mean and I will tell you what it means to me.

(I like best texts that talk back. And women.)

In Numbers there is safety. And certainty. Proof. Evidence. Overwhelmingly undeniable, line after line after line. Women have no responsibility whatsoever for male generation. Sons of their fathers. And the sins of the fathers shall not be visited on those who have never been named mothers. Absolvo te ... You shouldn't, really, you are too kind.... No, I insist...

Keep talking back and front and round about disturbing patriarchal plots. Dadababble.

Queen Esther, daughter of Abigail, wrote with full authority ..... that the Day of Destruction, the fourteenth of Adar, would ever after be a day of celebration for all her people.

The Book of Esther (Ishtar)

REVELATION (OED): Select an appropriately relevant meaning.

1. Disclosure of facts made by a person; exposure of something previously disguised or concealed.

And we saw

what we saw

and we didn't see

what was hidden

(Rita Ann Higgins)

What are the facts? Some call them 'data', some 'empirical research'. Some don't call them at all. Constructing airy immaterial edifices.

THEORY (OED): Contemplation, speculation, sight. From the Greek, Theor, the root, spectator. 
Roots are at the root of it all, one way and another, although it's the spectating that bothers me. Am I complicit in the enterprise I abhor? Out of my depth or in over my head?

Some call them home truths. We examined our own lives and found that everything out there was kicking our behinds - race, class, sex and homophobia. We saw no reason to rank oppressions ...

(Barbara Smith)

The issue is not one of elaborating a new theory ... but of jamming the theoretical machinery itself, of suspending its pretensions to the production of a truth and of a meaning that are excessively univocal.

(Luce Irigaray)

The question then is about beginning the stories —or the possibilities - openings, origins.

'Doesn't every narrative lead back to Oedipus?'

Barthes, plaintive.

Simply, no. All origins are not the same. All points of origin do not converge. Where they lead is more than one story, where they start quite another more than one.

The home truths are that some, many, most have been making do, with odds and ends, making ends meet, without access to anything much in the way of origins. My mother and I work to unravel the knot. Aurora Levins Morales.

Tell me a theory, tell me a theory ......

My mother forgot to tell me a grand narrative. Intolerable trauma.

Put them all on hold - just to cover all eventualities. Cancel the myths of the men of power so they no longer overwrite the unwritten truths of the peripherals.

Tell me a riddle.

(Tillie Olsen)

Riddle:

When is a truth not a truth? When it is untold for the silence is a lie.

Unwritten fears and terrors, poverties (as plural as riches - more so), deprivations, exploitations, colonisations, oppressions. Scientific Rationality is clearly dysfunctional for many many people.

(Sandra Harding)

And Progress?

The displacing power of all texts derives finally from the displacing power of the bible, whose centrality, potency and anteriority informs all Western literature.

(Edward Said) 
All? Always and forever? Amen. There are some, many, most who could do with a bit of placing and replacing first.

(Who do my smooth tongues displace?)

Woman is a position from which a feminist politics can emerge. (Linda Alcoff)

A position? No flesh no bones? Just juxtaposition disposition preposition imposition post-position post-modern post-deconstruction post-late-capitalist post-feminist post-woman and all the rest of it into the postbox. Well, now I know my flesh is a position. Sex is a position. Class is a position. Race, nationality, a position.

All position is suspect. No, I suspect their suppositions.

Meanwhile their myths

Meanwhile their meanings

Meanwhile their maimings

Meanwhile what has been changing for women? black brown white poor rich and getting by working class middle class healthy poorly and just up and down east west north south (you're always south of someone) able unable disabled by tyranny injustice weariness neglect indifference - and position.

Less poverty less violence less prostitution less hatred less division less silence? More food more literacy more housing more freedom more connection more affection?

No no no. Worse if anything.

\section{Riddle:}

Where is the middle of the world? Here.

So let us begin with our beginnings here and now with what we have and where we are. Desiring more but at least not less than what it is.

I am what I am, Take it or leave me alone.

\section{(Rosario Morales)}

Yes, and it's the truth; it's my truth. You can take it or leave it but that's the way I see it.

\section{(Bernice Johnson Reagon)}

Now there will be a little description of the coming to be history of all men and women, in some one. This is then to be a little history of such a one. This is then now to be a little description of loving repeating being in one.

\section{(Gertrude Stein)}

Telling the apparently trivial and the ordinary making meaning from the seeming in-significance of: living loving eating pleasing smoking scoldidng drinking dancing thinking working walking talking laughing sleeping suffering joking everything in them.

\section{(Gertrude Stein)}


Believe it, what we lost is here in this room

on this veiled evening.

The woman finishes. The story ends.

The child, who is my mother, gets up, moves away.

In the winter air, unheard, unshared,

the moment happens, hangs fire, leads nowhere.

The light will fail and the room darken,

the child fall asleep and the story be forgotten.

Eavan Boland What We Lost in Outside History

What we lost is for the finding in the doing and the knowing and the living and telling. Although, in truth, no loss of what we never had. No sentiment no nostalgia. If the 'grand narrative' is truly dead, amen, so be it, toodle oo!

But remember. Make an effort to remember. Or failing that, invent.

(Monique Wittig)

Jam up the system with 'dizzying accumulations' of tales of this and that and all the others, tales I tell my mother sisters and vice versa. Heads and tales no winning or losing just telling it as it is, was in the beginning and may still become.

Not grandiose solutions but particular negotiations located, limited, inescapably partial and always personally invested. Susan Bordo. Not dancing in frantic frenzy to the tuneless theories of disorder and deconstruction. Free, each one, to celebrate her own uncertainties in her own time and place.

Myriad overlapping stories always beginning originating in lived reality theory-inthe-flesh politics in the bones.

Polyvalent polygenesis.

\section{THIRD BEGINNING \\ or \\ THE END OF THE LINE}

I am a magpie. One for sorrow two for joy three for a wedding four for a boy five for silver six for gold seven for a secret that's never been told. And eight for a story.

Once twice many times upon a place. Singing and listening and gardening and telling.

Crazy talk. Raving.

Rave: Relevant but inappropriate definitions. Not OED. Karla Jennings, USA, Tales of the Computer Age. 
1. To babble on authoritatively about a subject one knows little about.

2. To insist on discussing something no one else wants to talk about.

Me and the grand narratives, thinking just associatively, of course.

Someday I'll tell it straight

as it comes

top to toe

with a sense of an ending

and then I'll just quietly die.

Which may or may not be true but it's the end of this particular line for the present and for what it's worth and for wherever it may lead.

END

\section{REFERENCES}

Aiken, Susan Hardy. 1990. Isak Dinesen and the Engendering of Narrative Chicago. University of Chicago P.

Anzaldua, Gloria and Moraga, Cherrie (eds). 1997 (1981). This Bridge Called My Back: Writings by Radical Women of Color. NY: Kitchen TableWomen of Color Press.

Boland, Eavan. 1990. Outside History Manchester: Carcanet Press.

Childers, Mary and Hooks, Bell. 1990. 'A Conversation about Race and Class' in Conflicts in Feminism ed. M. Hirsch and E. Fox Keller.London / New York: Routledge.

Grahn, Judy. 1989. Really Reading Gertrude Stein: A Selected Anthology with Essays by Judy Grahn. Freedom, California: The Crossing Press.

Haraway, Donna. 1990. 'A Manifesto for Cyborgs: Science, Technology, and Socialist Feminism in the 1980s' in Feminism/Postmodernism ed. Linda J. Nicholson. London / New York: Routledge.

Harding, Sandra. 1990. 'Feminism, Science and the Anti-Enlightenment Critiques' in Feminism/Postmodernism ed. Linda J. Nicholson. London / New York: Routledge.

Higgins, Rita Ann. 1988. Witch in the Bushes - Poems. Galway: Salmon Publishing.

Hirsch, Marianne and Fox Keller, Evelyn (eds). 1990. Conflicts in Feminism. London/New York: Routledge.

Jennings, Karla. 1990. The Devouring Fungus: Tales of the Computer Age. New York: W.W. Norton.

Morales, Aurora Levins. 1997 (1981). '...And Even Fidel Can't Change That' in This Bridge Called My Back: Writings by Radical Women of Color ed. G. Anzaldua and C. Moraga. NY: Kitchen TableWomen of Color Press.

Morales, Rosario. 1997 (1981). 'I Am What I Am' in This Bridge Called My Back: Writings by Radical Women of Color ed. G. Anzaldua and C. Moraga. NY: Kitchen TableWomen of Color Press.

Nicholson, Linda J. 1990. Feminism/Postmodernism. London / New York: Routledge.

Rees, Alwyn and Rees, Brinley. 1961. Celtic Heritage: Ancient Tradition in Ireland and Wales. London: Thames and Hudson.

Scott, Gail. 1989. Spaces Like Stairs: Essays. Toronto: The Women's Press.

Smith, Barbara (ed). 1983. Home Girls: A Black Feminist Anthology. NY: Kitchen TableWomen of Color Press.

Stanworth, Michelle. 1990. 'Birth Pangs: conceptive Technologies and the Threat to Motherhood' in Conflicts in Feminism ed. M. Hirsch and E. Fox Keller. London / New York: Routledge

Walker, Alice. 1983. In Search of Our Mother's Gardens: Womanist Prose. New York: Harcourt Brace Jovanovich Publishers.

Wittig, Monique. 1969. Les Guerilleres Paris: Editions de Minuit. 